\title{
溶融亜鉛めっき鉄筋の単一腐食及び異種金属接触腐食における 防食挙動に関する研究

\author{
A STUDY ON ANTI CORROSION BEHAVIOR OF GALVANIZED STEEL REBAR \\ IN CONCRETE UNDER GENERAL AND GALVANIC COUPLED ENVIRONMENT
}

\author{
崔 ホンボク*1, 西尾悠平*2, 兼松 学*3
}

Hongbok CHOE, Yuhei NISHIO and Manabu KANEMATSU

\begin{abstract}
An evaluation on anti-corrosion behavior of galvanized rebar, subjected to different corrosion acceleration (series1) and galvanic corrosion (series2), was carried out. Accelerated corrosion test with relatively lower anodic polarization rate and segmented rebar was used which simulated galvanic couple by ordinary rebar. In series1, galvanized rebar showed 1/4 times lower actual corrosion amount than designed one by corrosion test and no corrosion of substrate was found which implies continuous anti-corrosion effect of zinc. In series2, galvanic corrosion was generated on segmented rebar which was placed in the farthest from ordinary rebar. Moreover, formation of anodic current of macrocell was identified.
\end{abstract}

Keywords : Hot-dip galvanized steel reinforcement, Corrosion test rate, Totally applied current amount, Galvanic corrosion, Segmented rebar, Macrocell corrosion 溶融亜鉛めつき鉄筋，電食速度，積算電流量，異種金属接触腐食，分割鉄筋，マクロセル腐食

\section{1. はじめに}

近年，日本では高耐久性防食鉄筋として知られている溶融亜鉛め っき鉄筋(以下，めっき鉄筋)について, その防食性能を評価する研究 が活発に行われている1) 6)。めっき鉄筋は, 母材の鉄筋表面に形成さ れた亜鉛皮膜によって防食される。空気や水分の接触を防ぐ保護皮 膜作用に加え, 母材よりイオン化傾向の高い亜鉛が先行して腐食(ア ノード反応)する犠牲防食効果を有する。覀鉛によって母材はカソー ドとなり，亜鉛皮膜の消耗が続くまで腐食が抑制される。 ILZRO(International Lead Zinc Research Organization)が実施し ためっき鉄筋を適用した実構造物(築年数：3年〜 28 年)における亜鉛 皮膜の厚さの調查によると, 亜鉛皮膜は約 $100 \mu \mathrm{m}$ 以上残っており, 母材の腐食はほとんどみられなかったと報告している7) 11)。また， 土木学会が実施した沖縄美ら海水族館(施工年：1992年)の調査によ ると，亜鉛皮膜は約 $80 \mu \mathrm{m}$ 以上残っており，腐食電流密度は 0.2 $\mu \mathrm{A} / \mathrm{cm}^{2}$ 未満であると報告している12)。このようにめつき鉄筋は鉄筋 コンクリート造建築物の腐食抑制対策としてその利用が期待されて いる13）。一方，めっき鉄筋を実用化するためには，腐食時のめっき 鉄筋が有する耐久性の確認に加え，普通鉄筋との併用を想定しため つき鉄筋の部分適用について検討する必要がある。

鉄筋腐食における耐久性の確認には，一般的に電食試験などの腐 食促進試験が利用されている。電食試験は外部の定電流装置を用い て一定のアノード電流を流し鉄筋の腐食を誘導する方法であり, 電 食時間と印加電流密度を乗じた積算電流量の設定によって，腐食進
行における鉄筋の腐食速度や腐食量を定量的に評価することが可能 である。そのため，既往の研究では普通鉄筋の腐食挙動を評価する ために電食試験が活用されており 14) 22)，めっき鉄筋においても積算 電流量による亜鉛皮膜の腐食量や防食性能の定量評価に有効な方法 と考えられる。しかし，めっき鉄筋の腐食挙動に関して, 暴露または 浸漬試験を用いた研究事例は多いものの ${ }^{3) ~ 6)}$, 電食試験を用いた事 例はほとんどないのが現状である23),24)。そのため, 電食試験のめつ き鉄筋への適用性を検討寸る一環として, 丹羽1)らは印加電流密度を $0.625 \mathrm{~mA} / \mathrm{cm}^{2}$ とし，めっき鉄筋の単一腐食を評価する電食試験を行 った。しかし, 亜鉛皮膜の実際の腐食量が $43 \%$ の時点でめっき鉄筋の 母材に腐食(赤錆)が生じる結果となり, $50 \%$ 以上の亜鉛皮膜の残存に も関わらず亜鉛の犠牲防食効果が機能しなくなっていた。犠牲防食 効果が早く終了した要因として, 電食速度が高速(印加電流密度が高 く，腐食促進が急速に進行)であったためと考えられる。

また，めつき鉄筋を普通鉄筋と併用する場合，異種金属接触腐食(以 下，異種間腐食)が生じる恐れがある。異種間腐食は，外部の普通鉄筋 との接触によってめっき鉄筋がアノード部(普通鉄筋はカソード部) となり，接触部の腐食が促進される現象である25)。そのため，めっき 鉄筋と普通鉄筋が接触した際の異種間腐食の影響について検討され てきた1),2),4)。しかし，鉄筋の全面積に対する平均の腐食速度を測定 するため, 単体のめっき鉄筋では接触によって局部腐食する範囲の定 量評価が困難であり, その検討は十分とは言えない。以上のことから, 本研究では, 比較的低速の印加電流密度にした電食試験によって単一
*1 東京理科大学理工学研究科建築学専攻 大学院生・修士 (工学)

*2 東京理科大学理工学部建築学科 助教 - 博士 (工学)

*3 東京理科大学理工学部建築学科 教授 $\cdot$ 博士 (工学)
Grad. Student, Dept. of Architecture, Grad. School of Sci. and Tech., Tokyo Univ. of Sci., M.Eng:

Assist. Prof., Dept. of Architecture, Faculty of Sci. and Tech., Tokyo Univ. of Sci., Dr.Eng. Prof., Dept. of Architecture, Faculty of Sci. and Tech., Tokyo Univ. of Sci., Dr.Eng. 
腐食及び異種間腐食の環境にあるめつき鉄筋が正常に腐食するかを 検討し，その際のめっき鉄筋の防食挙動の評価を目的とした。シリー ズ1では単体のめっき鉄筋に対し亜鉛皮膜の犠牲防食効果を，シリー ズ2では局部腐食(マクロセル腐食)の評価に有効である分割鉄筋法 26) 28)を用いてめっき鉄筋の異種間腐食が影響する範囲を評価した。

\section{2. 研究概要}

\section{1）実験因子および水準}

(1) シリーズ1

Table1に試験体一覧及び実験因子を示す。試験体名のWは水セメ ント比，Dは印加電流密度を示している。W/Cは50\%とした。本実験 では，印加電流密度と積算電流量による亜鉛皮膜の計画腐食量(表中 のDCA)を実験因子とした。印加電流密度は丹羽ら ${ }^{1)}$ が行った電食速 度 $\left(0.625 \mathrm{~mA} / \mathrm{cm}^{2}\right)$ より比較的低速の範囲で設定し, $0.16,0.08$, $0.02 \mathrm{~mA} / \mathrm{cm}^{2}$ の3水準とした。普通鉄筋を対象に電食を行った既往の 研究は, 海外ではEI Maaddawyら 21)によって, 日本では高谷ら 17)によ って整理されている。既往研究において電食速度は0.04 $10 \mathrm{~mA} / \mathrm{cm}^{2}$ と 幅広い条件で設定されているが，主には0.1 2 $\mathrm{mA} / \mathrm{cm}^{2}$ の範囲で実施さ れている14) 22)。従って，試験対象とした鉄筋は異なるが，本実験に おける電食速度は既往研究で行った設定水準にありつつ, その内, 相当低い範囲にあるように設定した。計画腐食量は, 電食による亜 鉛皮膜の予想腐食量を意味する。亜鉛皮膜のみが腐食するように設 定するために，膜厚計で測定した健全なめっき鉄筋の亜鉛皮膜の平 均厚さ $(180 \mu \mathrm{m})$ を $100 \%$ とし, 積算電流量の調整によって亜鉛皮膜が $25 \%(45 \mu \mathrm{m}) \sim 100 \%(180 \mu \mathrm{m})$ まで消耗することにした。計画腐食量ま で電食を連続するために各計画腐食量の試験体をそれぞれ用意した。

Table1 Specimen list (series 1)

\begin{tabular}{|c|c|c|c|c|}
\hline No & Specimen & $\begin{array}{l}\text { Applied current } \\
\text { density }\left(\mathrm{mA} / \mathrm{cm}^{2}\right)\end{array}$ & $\begin{array}{l}\text { Surface area of } \\
\text { rebar }\left(\mathrm{cm}^{2}\right)\end{array}$ & $\operatorname{DCA}(\%)$ \\
\hline 1 & \multirow{4}{*}{ W50-D160 } & \multirow[t]{4}{*}{ 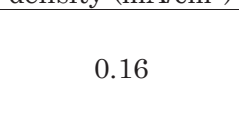 } & \multirow[t]{4}{*}{ 10, } & 25 \\
\hline 2 & & & & 50 \\
\hline 3 & & & & 75 \\
\hline 4 & & & & 100 \\
\hline 5 & \multirow{4}{*}{ W50-D80 } & \multirow{4}{*}{0.08} & \multirow{4}{*}{125} & 25 \\
\hline 6 & & & & 50 \\
\hline 7 & & & & 75 \\
\hline 8 & & & & 100 \\
\hline 9 & \multirow{3}{*}{ W50-D20 } & \multirow{3}{*}{0.02} & \multirow{3}{*}{500} & 25 \\
\hline 10 & & & & 50 \\
\hline 11 & & & & 75 \\
\hline
\end{tabular}

\section{(2) シリーズ2}

Table2に実験因子および水準を示す。めつき鉄筋が異種間腐食す る環境はコンクリート中を想定し, 腐食条件は電食試験による促進 腐食とした。W/Cは $45 \%$ とし, 試験体は水道水中に浸漬した。また, 腐食進行におけるめっき鉄筋の異種間腐食電流を測定するために, 電食試験による亜鉛皮膜の計画腐食量を水準とした。計画腐食量は シリーズ 1 と同様であり, シリーズ 2 においても低速の印加電流密度 を与えるために $0.16 \mathrm{~mA} / \mathrm{cm}^{2}$ とし，鉄筋表面積は $62.5 \mathrm{~cm}^{2}$ とした。

Table3に試験体一覧を示す。試験体名について, Aは電食による促 進腐食を示しており，亜鉛皮膜の計画腐食量の進行を示すために数 值で表した。腐食電流の測定はマクロセル電流, ミクロセル電流の 順に行った。25\%の計画腐食量ごとに測定し, 電食が終了したときを 最終の測定時点とした。腐食電位はミクロセル電流の測定前に行っ た。測定時は電食を一時中止し, 測定後に電食を再開始した。
Table2 Scope of the experiment (series 2)

\begin{tabular}{c|c}
\hline Experiment condition & Scope \\
\hline Galvanic corrosion environment & $\begin{array}{c}\text { In concrete and } \\
\text { immersed in tap water }\end{array}$ \\
\hline $\begin{array}{c}\text { Corrosion test method } \\
\text { (Applied current density) }\end{array}$ & $\begin{array}{c}\text { Galvanostatic technique } \\
\left(0.16 \mathrm{~mA} / \mathrm{cm}^{2}\right)\end{array}$ \\
\hline $\begin{array}{c}\text { Designed corrosion amount of } \\
\text { zinc coating (hereafter, DCA) }(\%)\end{array}$ & $25,50,75,100$ \\
\hline
\end{tabular}

Table3 Specimen list (series 2)

\begin{tabular}{|c|c|c|c|c|}
\hline No & Specimen & $\begin{array}{c}\text { Composition of } \\
\text { segmented rebar }\end{array}$ & $\begin{array}{c}\mathrm{DCA} \\
(\%)\end{array}$ & $\begin{array}{l}\text { Measurement } \\
\text { of current }\end{array}$ \\
\hline 1 & $A-1$ & \multirow{4}{*}{$\begin{array}{c}\text { Galvanized rebar } \\
(12 \mathrm{ea}) \\
+ \\
\text { Ordinary rebar (1ea) }\end{array}$} & 25 & \multirow{4}{*}{$\begin{array}{c}\text { Every } 25 \% \\
\text { interval } \\
\text { of DCA }\end{array}$} \\
\hline 2 & $A-2$ & & 50 & \\
\hline 3 & $A-3$ & & 75 & \\
\hline 4 & $A-4$ & & 100 & \\
\hline
\end{tabular}

\section{2) 試験体概要}

(1) シリーズ1

Table4に試験体製作に用いたコンクリート調合表および性状を， Fig.1に試験体概要を示す。めつき鉄筋は1本の異形鉄筋(D16)を使用 し，コンクリートは $100 \mathrm{~mm} \times 100 \mathrm{~mm}$ の断面寸法で製作した。長手方 向の寸法は, Table1に示した各水準の鉄筋表面積に必要な鉄筋長さ を考慮して作製した。両端はエポキシ系接着剤を塗って絶縁し，片 方に導線をつけてめっき鉄筋が電食時の陽極になるようにした。

Table4 Mix proportion of concrete for specimen (series 1)

\begin{tabular}{c|c|c|c|c|c|c|c}
\hline \multirow{2}{*}{$\begin{array}{c}\text { W/C } \\
(\%)\end{array}$} & \multicolumn{5}{|c|}{ Unit weight $\left(\mathrm{kg} / \mathrm{m}^{3}\right)$} & \multirow{2}{*}{$\begin{array}{c}\text { Air } \\
(\%)\end{array}$} & $\begin{array}{c}\text { Slump } \\
(\mathrm{cm})\end{array}$ \\
\cline { 2 - 6 } & $\mathrm{W}$ & $\mathrm{C}$ & $\mathrm{S}$ & $\mathrm{G}$ & $\mathrm{Ad}$ & & \\
\hline 50 & 185 & 370 & 796 & 943 & 1.85 & 3.0 & 18.9 \\
\hline
\end{tabular}

$<$ Cross Section>

<Side>

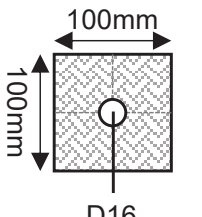

D16

Deformed Bar

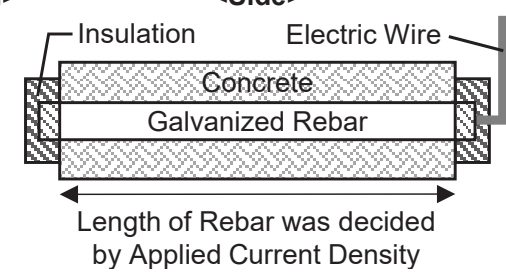

Fig.1 Specimen preparation (series 1)

\section{(2) シリーズ2}

Table5にコンクリート調合およびフレッシュ性状を，Fig.2に分割 鉄筋試験体の概要を示す。D16の異形鉄筋を一定長さに切り, 1 個の 鉄筋要素断面の両端に赤と黒の導線をそれぞれはんだ付けし，その 上にエポキシ系接着剤を塗り絶縁した。本実験では，めっき鉄筋と 普通鉄筋の異種間腐食を模擬するために, Table3に示したように試 験体の構成を普通鉄筋が 1 個, めつき鉄筋が 12 個とした。この後, 全 ての鉄筋要素が一本の鉄筋となるようエポキシ系接着剤で各鉄筋要 素を接着し分割鉄筋試験体を作製した。普通鉄筋は中央に配置し, 隣接した鉄筋要素は赤線と黒線の導線が向かい合うようにした。

赤線と黒線の短絡(例えば, 鉄筋要素(1)の赤線と(2)の黒線)によって 試験体は電気的に一体化した単体鉄筋と同様となり，普通鉄筋とめ っき鉄筋の短絡は異種間腐食の環境となる。さらに, 短絡時の電流 の出入りは鉄筋要素の順番通りに流れる。従って, 本構成によって, 異種間腐食の接触部は普通鉄筋付近の鉄筋要素(中央部 : 4 6 6 8 10), 未接触部はそれより離れた遠方の鉄筋要素(外側部：1 3と 11 13) と して想定することができ，それぞれの腐食挙動が評価できる。 
Table5 Mix proportion of concrete for specimen (series 2)

\begin{tabular}{c|c|c|c|c|c|c}
\hline \multirow{2}{*}{$\begin{array}{c}\text { W/C } \\
(\%)\end{array}$} & \multicolumn{4}{|c|}{ Unit weight $\left(\mathrm{kg} / \mathrm{m}^{3}\right)$} & \multirow{2}{*}{$\begin{array}{c}\text { Air } \\
(\%)\end{array}$} & \multirow{2}{*}{$\begin{array}{c}\text { Slump } \\
(\mathrm{cm})\end{array}$} \\
\cline { 2 - 5 } & $\mathrm{W}$ & $\mathrm{C}$ & $\mathrm{S}$ & $\mathrm{G}$ & & 17.8 \\
\hline 45 & 180 & 400 & 783 & 942 & 8.5 & 172 \\
\hline
\end{tabular}

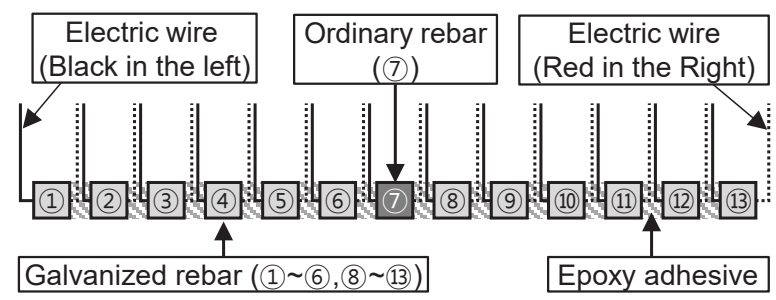

Fig.2 Specimen setup by segmented rebar (series 2 )

\section{3）実験手法：電食試験(シリーズ1とシリーズ2)}

Fig.3にシリーズ1の電食試験の概要を示す。試験体は水道水中に 浸漬させ，水槽の下に対極としてステンレス(SUS)板を設けた。対極 とコンクリートの下面は接しないようにし，めっき鉄筋につけた導 線は定電流装置の $(+)$ 側, SUS板は(-)側に接続した。定電流装置を 用いて定電流を印加することで電食を開始した。印加電流は最低值 である $10 \mathrm{~mA}$ と固定し, 鉄筋の表面積 $\left(=\Pi \cdot \mathrm{D} \cdot \mathrm{L}\left(\mathrm{cm}^{2}\right)\right)$ で除することで 印加電流密度を合わせた。電食後, 分極実験によりめっき鉄筋の電 気化学特性を評価した上で，亜鉛皮膜の実際の腐食量を測定した。

Fig.4にシリーズ2の電食試験の概要を示す。コンクリートの断面 寸法，両端の絶縁，浸漬方法はシリーズ1と同様にした。分割鉄筋試 験体をすべて短絡した上で, シリーズ 1 と同様に定電流を印加 $(10 \mathrm{~mA}) し て$ 電食を開始した。本実験の試験体は，異種金属が短絡し た条件でめっき鉄筋と普通鉄筋それぞれが有する見掛けの腐食挙動 を把握するために構成されている。そのため, 腐食環境において両 鉄筋とも定電流装置のアノード電流が流れるように電食を施した。 なお，電食は試験体の材齢28日以降で実施した。

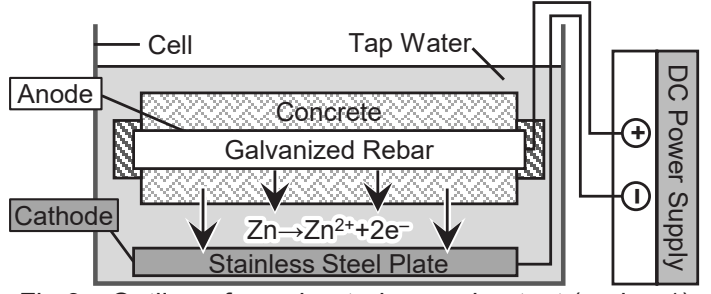

Fig.3 Outline of accelerated corrosion test (series 1)

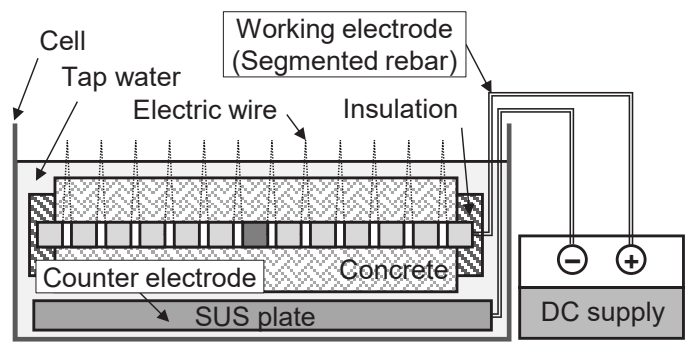

Fig.4 Outline of accelerated corrosion test (series 2)

Table6に計画腐食量における積算電流量と電食時間の算定を示す。 ファラデー則より, 亜鉛の腐食電流密度 $\left(\mu \mathrm{A} / \mathrm{cm}^{2}\right)$ と腐食速度 $(\mu \mathrm{m} /$ year $)$ は式(1)のような関係にある。ここで, 右辺の腐食速度から 時間(year)を移項すると, 式(2)のように積算電流量 $\left(\mathrm{mA} \cdot \mathrm{h} / \mathrm{cm}^{2}\right)$ にお
ける亜鉛の腐食量 $(\mu \mathrm{m})$ が算定できる。本実験では式(2)に基づき， 各々の計画腐食量に対応する所要の積算電流量を求め, 水準とした 電食試験の印加電流密度に割ることで所要の電食時間を算出した。

$1 \mu \mathrm{A} / \mathrm{cm}^{2} \approx 14.98 \mu \mathrm{m} /$ year

左辺 : 亜鉛の腐食電流密度, 右辺 : 亜鉛の腐食速度

$1 \mathrm{~mA} \cdot \mathrm{h} / \mathrm{cm}^{2} \approx 1.71 \mu \mathrm{m}$

ただし, 左辺 : 積算電流量, 右辺 : 亜鉛の腐食量

Table6 Calculation of applied current amount and test period

\begin{tabular}{c|c|c|c|c}
\hline $\begin{array}{c}\text { DCA } \\
(\%)\end{array}$ & $\begin{array}{c}\text { Corrosion } \\
\text { amount of } \\
\text { zinc }(\mu \mathrm{m})\end{array}$ & $\begin{array}{c}\text { Required } \\
\text { current amount } \\
\left(\mathrm{mA} \cdot \mathrm{h} / \mathrm{cm}^{2}\right)\end{array}$ & $\begin{array}{c}\text { Applied } \\
\text { current density } \\
\left(\mathrm{mA} / \mathrm{cm}^{2}\right)\end{array}$ & $\begin{array}{c}\text { Corrosion } \\
\text { test period } \\
(\mathrm{h})\end{array}$ \\
\hline 25 & 45 & 26.32 & & 164.50 \\
\hline 50 & 90 & 52.63 & \multirow{2}{*}{0.16} & 328.94 \\
\hline 75 & 135 & 78.95 & & 493.44 \\
\hline 100 & 180 & 105.26 & & 657.88 \\
\hline
\end{tabular}

\section{4）腐食挙動の評価}

(1) 分極実験(シリーズ1)

Fig.5に定電位分極法を用いた分極実験の概要を示す。参照極は $\mathrm{Ag} / \mathrm{AgCl}$ ，作用極はめっき鉄筋，対極はSUS板を使用した。電位走查 速度は $1 \mathrm{mV} / \mathrm{S}$ とし，アノード分極は安定した自然電位の值から $+250 \mathrm{mV}$ まで,カソード分極は $-250 \mathrm{mV}$ の範囲まで行った。腐食電流 密度は式(3)に示すStern-Gearyの式より求めた。分極から得られた 電流 $(\mathrm{E})$ 一電位 $(\log \mathrm{I})$ グラフを用い， $b_{a}$ と $b_{c}$ は腐食電位より $\pm 100 \mathrm{mV}$ 以 上の值から直線区間から算出し, $R_{p}$ は腐食電位から $\pm 10 \mathrm{mV}$ 範囲の直 線の傾き $(\Delta \mathrm{E} / \Delta \mathrm{I})$ からそれぞれ算出した。

$i_{\text {corr }}=B \times R_{p}^{-1}=\left[\left(B_{a} \times B_{c}\right) /\left\{2.3 \times\left(B_{a}+B_{c}\right)\right\}\right] \times R_{p}{ }^{-1}$

$i_{\text {corr }}$ : 腐食電流密度 $\left(\mu \mathrm{A} / \mathrm{cm}^{2}\right), B$ : ターフェル定数 $(\mathrm{mV}), B_{a}, B_{c}:$ ア ノードおよびカソード勾配 $\left(\mathrm{mV} /\right.$ decade),$R_{p}$ : 分極抵抗 $\left(\Omega \times \mathrm{cm}^{2}\right)$

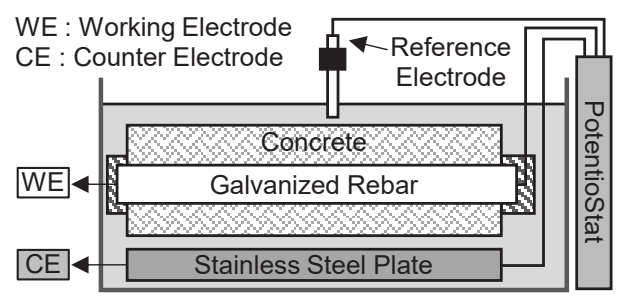

Fig.5 Outline of polarization test (series 1)

\section{（2）ミクロセル腐食電流の測定(シリーズ2)}

Fig.6にミクロセル腐食電流の測定概要を, 式(4)に算出方法を示寸。 ミクロセル腐食電流は, 各鉄筋要素にアノード反応とカソード反応 が正常状態で生じる現象であり，めっき鉄筋の腐食挙動を評価する 基準のひとつである。本実験では, 短絡した鉄筋要素を全て分離し, 定電位分極法を用いてミクロセル腐食電流を測定した。電位の走查 は $0.5 \mathrm{mV} / \mathrm{S}$ とし, 測定した自然電位 $(\mathrm{mV})$ より $+15 \mathrm{mV}$ までアノード分 極を, $-15 \mathrm{mV}$ までカソード分極を行った。得られた電位 $(\mathrm{E})$ 一電流( $\mathrm{I})$ グラフを用い, 自然電位より $\pm 10 \mathrm{mV}$ の範囲内の傾き $(=\Delta \mathrm{E} / \Delta \mathrm{I})$ から分 極抵抗 $\left(\mathrm{R}_{\mathrm{p}}\right)$ を算出し, ミクロセル腐食電流密度は式(4)より算出した。 なお，測定時間は宮里ら 27$)$ の研究を参考に，1時間以内とした。 $b_{i}=\left\{K /\left(R_{p} \times S_{i}\right)\right\} \times 10^{6}$ $b_{i}$ : 鉄筋要素 $\mathrm{i}$ のミクロセル電流密度 $\left(\mu \mathrm{A} / \mathrm{cm}^{2}\right), K$ : アノード, カソー ド分極におけるターフェル定数 $(52 \mathrm{mV}), R_{p} \times S_{i}: \mathrm{i}$ の分極抵抗 $\left(\Omega \times \mathrm{cm}^{2}\right)$ 


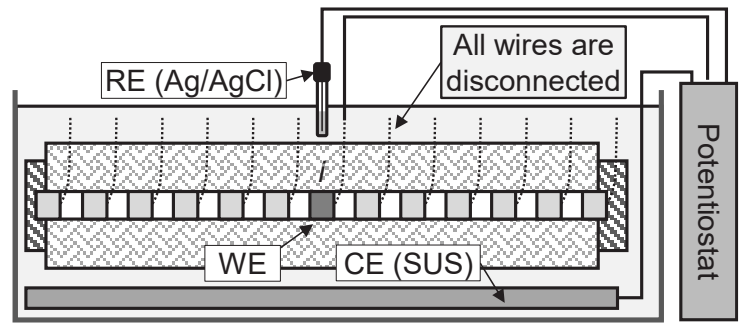

Fig.6 Measurement of microcell corrosion current (series 2)

\section{（3） マクロセル腐食電流の測定(シリーズ2)}

Fig.7にマクロセル腐食電流の測定概要を, 式(5)に算出方法を示寸 隣接する赤線と黒線を 1 台の無抵抗電流計に接続し, 全ての鉄筋要素 も同様に行った。鉄筋要素間に流れる電流を測定することで，各鉄 筋要素のマクロセル腐食電流密度を式(5)より求めた。正(+)の值はア ノード電流密度を，負(-)の值はカソード電流密度を示す。

一般に，マクロセル腐食は，コンクリートのひび割れ部あるいは 塩化物が集中して浸透した部位の形成によって, 鉄筋に異常なア, 一ド領域が生じ, 局部的な腐食が進む現象である26),27)。本研究では, 普通鉄筋の存在が付近のめっき鉄筋にマクロセル腐食電流を誘導す ると想定した。さらに, 分割鉄筋が挙動するマクロセル腐食電流の 分布によって異種間腐食の影響範囲が定量的に評価できると判断し た。なお, 宮里ら 26)の研究によると, マクロセル腐食電流の正確な 測定には鉄筋要素の長さが影響し, $1.5 \mathrm{~cm}$ 以下とする必要があると報 告されている。そのため, 本実験では分割鉄筋試験体の所要表面積 $\left(62.5 \mathrm{~cm}^{2}\right)$ に対応する所要長さ $(12.43 \mathrm{~cm})$ において鉄筋要素の長さを 約 $0.95 \mathrm{~cm}$ とし，合計13個の鉄筋要素を用いることにした。

$a_{i}=\left(A_{i, i+1}-A_{i, i-1}\right) / S_{i}$

$a i$ : 鉄筋要素iのマクロセル腐食電流密度 $\left(\mu \mathrm{A} / \mathrm{cm}^{2}\right), A_{i, i+1}, A_{i, i-1}: \mathrm{i}$ と 隣接した鉄筋要素のマクロセル腐食電流 $(\mu \mathrm{A}), S_{i}: \mathrm{i}$ の表面積 $\left(\mathrm{cm}^{2}\right)$

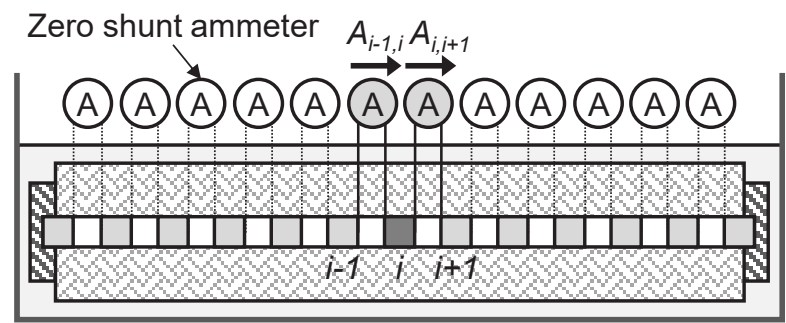

Fig.7 Measurement of macrocell corrosion current (series 2)

\section{（4）実際の腐食量の測定(シリーズ1とシリーズ2)}

電食試験の終了後, 計画腐食量との比較のためにコンクリートか らめっき鉄筋をはつり出し, 式(6)を用いて実際の腐食量を求めた。 金ブラシを用いて鉄筋表面に着いたコンクリートと亜鉛腐食物を除 去した。この後, 残りの亜鉛皮膜はJIS H 0401:201329)に準拠して除 去した。蒸留水 $500 \mathrm{ml}+$ 質量分率 $35 \%$ の塩酸 $500 \mathrm{ml}$ +ヘキサメチレン テトラミン $3.5 \mathrm{~g}$ の溶液にめっき鉄筋を溶かし, 水素気泡の発生終了 後に流水で鉄筋を洗い，乾燥後に質量を測定した。

$t=\left\{\left(\mathrm{W}_{1}-\mathrm{W}_{2}\right) / 7.2 \mathrm{~S}\right\} \times 10^{6}$

$t$ : 残りの亜鉛皮膜 $(\mu \mathrm{m}), \mathrm{W}_{1}$ : 亜鉛皮膜の除去前の質量 $(\mathrm{g}), \mathrm{W}_{2}$ : 亜鉛 皮膜の除去後の質量 $(\mathrm{g}), 7.2$ : 亜鉛密度 $\left(\mathrm{g} / \mathrm{cm}^{3}\right), \mathrm{S}$ : 鉄筋表面積 $\left(\mathrm{mm}^{2}\right)$
3. 結果と考察

1) シリーズ1

\section{（1）電食後めっき鉄筋の表面変化}

Fig. 8 に電食速度 $=0.08 \mathrm{~mA} / \mathrm{cm}^{2}$ の条件で腐食しためっき鉄筋表面 の様子を示す。また, 各々の計画腐食量における1本の鉄筋に対して, 上側と下側の両方の表面を示した。鉄筋表面上の黒色は酸化皮膜, 白色および灰色は亜鉛腐食物を表している。観察した結果，計画腐 食量が $25 \%$ 経過した時点でめっき鉄筋上に黒い酸化皮膜(以下，酸化 膜)が両面ともに形成し, 電食が計画腐食量 $100 \%$ まで経過しても酸 化膜が保たれた。ただし，鉄筋下面では酸化膜の上に亜鉛腐食物(灰 色は $\mathrm{ZnO}$ ，白色は $\mathrm{Zn}(\mathrm{OH})_{2}$ または $\left.\mathrm{ZnO}^{30}\right)$ が観察され，電食時間の経 過に従って増加寸る傾向にあった。これは，より対極に近い下面に おいて亜鉛腐食物の形成が先行したことによると考えられ、時間の 経過とともに領域を広げていったと推察される。それにも関わらず, コンクリート表面でのひび割れおよび母材の腐食による赤錆は生じ ず, いずれの計画腐食量においても均一な亜鉛腐食が生じたので, 亜鉛の犠牲防食効果が正常に機能していることが確認できた。さら に, 印加電流密度が異なるコンクリートにおいてもこの現象はほぼ 同様に現れた。一方, 鉄筋断面を観察した結果，めっき鉄筋に生じた 酸化膜はめっき鉄筋上に緻密に付着しつつ, 亜鉛皮膜は十分残って いることが確認された。酸化膜は亜鉛の腐食による生成物ではない が, 高速の電食を行った丹羽ら1の研究では見られなかった現象であ る。ところで，村上 ${ }^{31)}$ らによると，亜鉛めっき鋼材と接した材齢 28 日，91日のコンクリート表面は黒く変色したとの報告がある。また， Stark $5^{7}$ )が調查したLongbird橋(築年数 : 21 年) と Flatts橋(築年数 : 8年)においても亜鉛皮膜がそれぞれ $150 \mu \mathrm{m}, 210 \mu \mathrm{m}$ 残った時点でめ っき鉄筋表面が黒変したと報告している。従って, 本研究で水準と した低速の電食をうけためっき鉄筋では，亜鉛の犠牲防食効果に加 え酸化膜の形成が確認できたことから，実構造物におけるめっき鉄 筋とほぼ同様の腐食現象が現れたと考えられる。

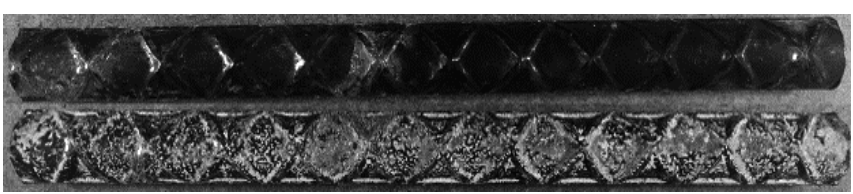

(a) $\mathrm{DCA}=25 \%$

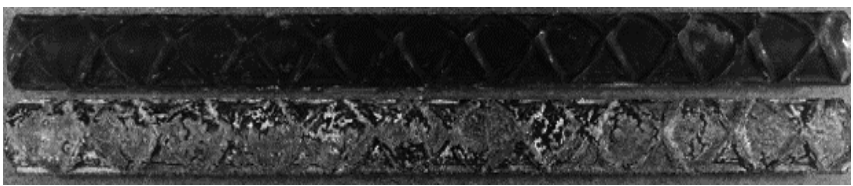

(b) $\mathrm{DCA}=50 \%$

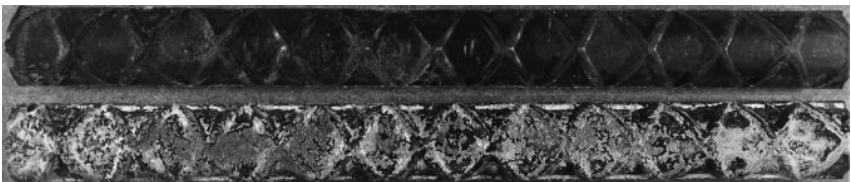

(c) $\mathrm{DCA}=75 \%$

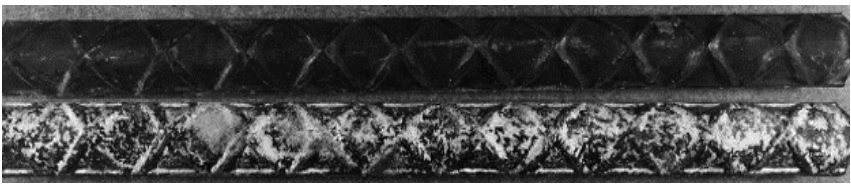

(d) $\mathrm{DCA}=100 \%$

Fig.8 Surface change of galvanized rebar at $0.08 \mathrm{~mA} / \mathrm{cm}^{2}$ (series 1 ) 
Fig.9はめっき鉄筋の腐食によって生じた酸化膜のXRD分析の結 果を示しており, 主な成分は $\mathrm{SiO}_{2}$ となった。Yeomans ${ }^{13)}$ らによると, めつき鉄筋の亜鉛皮膜の厚さやめっき層の構成を調整するために $\mathrm{Si}$ を添加するとの報告がある。また, 橋本の研究32)では, 電気 $\mathrm{Zn}-\mathrm{SiO}_{2}$ 複合めっきについて, $\mathrm{SiO}_{2}$ はめっき被膜中に残存し, めっき被膜の 溶解を制御して耐食性を高めるとの報告がある。一方，村上 ${ }^{31)}$ らが 分析したXRDの結果によると, 亜鉛めっき鋼材表面の一部や, めっ き有無によらず鋼材に接したコンクリート表面にも $\mathrm{SiO}_{2}$ 吕確認され たとの報告もある。従って, 本実験においてめっき鉄筋上に $\mathrm{SiO}_{2}$ が 形成した原因は亜鉛皮膜の内部またはコンクリートによるものと考 えられる。また，本実験の結果では亜鉛腐食物を除去した後の鉄筋 表面に酸化膜が残存していた。従って, 酸化膜は亜鉛腐食の前に生 じたものと考えられる。しかし, 酸化膜が生じていても腐食が進行 したことから，酸化膜は亜鉛皮膜の初期に保護効果があり，亜鉛の 腐食開始以降では影響しないと考えられる。ただし, 酸化膜の形成 が低速の電食のみによる現象かどうかに関しては, 既往研究では報 告されておらず，また，同じ積算電流量において高速の電食を行っ た実験結果がないことから，今後の課題とする。

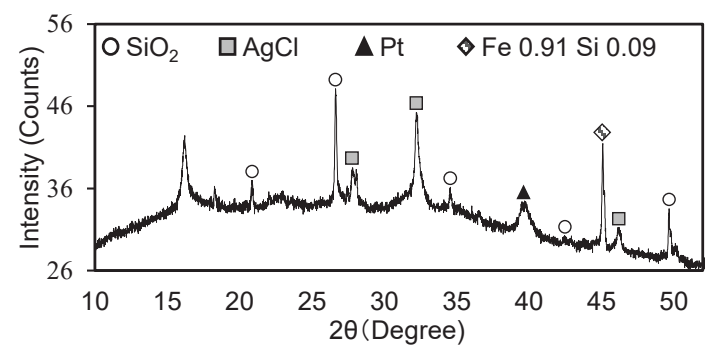

Fig.9 Property of Oxidation film by XRD analysis (series 1)

\section{（2）印加電流密度における分極抵抗の挙動}

Fig.10に電食進行におけるめつき鉄筋の分極抵抗を示す。計画腐 食量を設定するために基準とした健全なめっき鉄筋の亜鉛皮膜厚さ は1804mであった。しかし，式(6)を用い，試験体に使用しためっき 鉄筋の長さにおける予想の健全部質量 $\left(\mathrm{W}_{0}=1.56 \mathrm{~g} / \mathrm{mm}\right)$ と亜鉛除去後 $\left(\mathrm{W}_{2}\right)$ との質量差 $\left(\mathrm{W}_{0}-\mathrm{W}_{2}\right)$ から算出した結果，健全なめっき鉄筋は被 膜厚さ $155 \mu \mathrm{m}$ 有することが確認された。本研究では, 計画腐食量を 式(6)より求めた実際の腐食量と同じ基準厚さとなるように補正した。 Table6により，180umの亜鉛腐食に必要な積算電流量は105.26mA・ $\mathrm{h} / \mathrm{cm}^{2}$ である。ここで, $155 \mu \mathrm{m}$ を基準とすると, この積算電流量によ って亜鉛は $180 \mu \mathrm{m} / 155 \mu \mathrm{m} \approx 1.16$ 倍の腐食量となるので, 元の $100 \%$ の 計画腐食量は $116 \%$ と補正される。

計画腐食量の増加において, 電食が進行するほど分極抵抗は高ま っており，いずれの印加電流密度においてもほぼ同様な傾向が確認 された。また, 同一の計画腐食量では, 印加電流密度が低いほど分極 抵抗は高いことが確認された。橋本の研究 ${ }^{32}$ )では, 亜鉛めっきの亜 鉛による犠牲防食効果の他に亜鉛腐食物による防食効果についても 検討しており，亜鉛の激しい腐食によって生成される $\mathrm{ZnO}$ は耐食性 が発揮されないが, $\mathrm{Zn}(\mathrm{OH})_{2}$ は電気的に絶縁物なので, $\mathrm{Zn}(\mathrm{OH})_{2}$ の形 成によって耐食性が高くなると報告している。本実験によって腐食 させためっき鉄筋は，電食が進行するほど灰色より白色の亜鉛腐食 物の生成の方が著しかった。また, 同じ計画腐食量の印加電流密度
が異なるめっき鉄筋で比較すると, W50-D20の試験体で白色の亜鉛 腐食物が多く見られた。従って, 電食による亜鉛皮膜の腐食進行と は別に，めつき鉄筋の表面に生じた亜鉛腐食物は $\mathrm{Zn}(\mathrm{OH})_{2}$ と推定さ れ, 分極抵抗の増加に影響していると考えられる。よって, 今後の課 題として, 印加電流密度における $\mathrm{Zn}(\mathrm{OH})_{2}$ の形成挙動の検討が必要 と考えられる。従って, 本研究の範囲で検討しためっき鉄筋の電気 化学的挙動においては, 亜鉛の犠牲防食効果が機能寸る限り分極抵 抗は電食によって増加することが確認された。

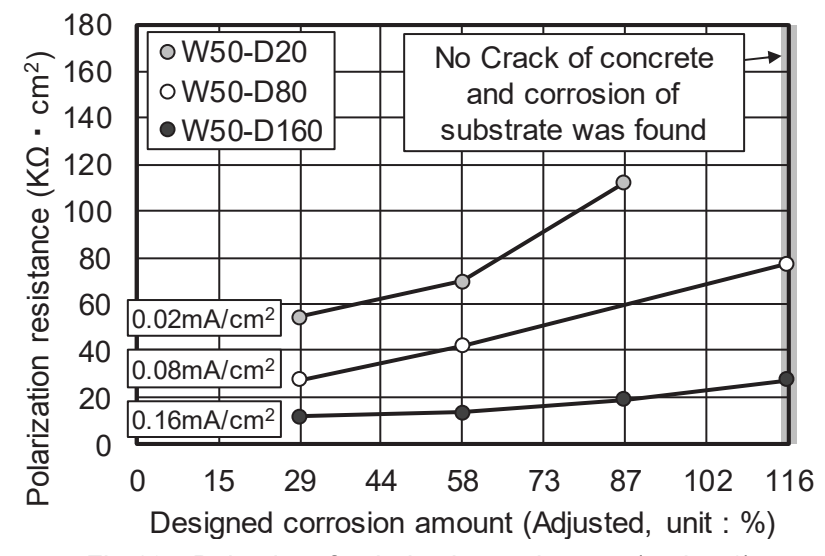

Fig.10 Behavior of polarization resistance (series 1)

\section{（3）質量変化から求めためっき鉄筋の実際の腐食量}

Fig.11にめっき鉄筋に実際に残存した亜鉛皮膜の厚さ(以下，残存 厚さ)を示す。計画腐食量 $29 \%$ の時点で残存厚さが増加しており, そ の後, 腐食進行によって減少する傾向がみられた。亜鉛皮膜の厚さ が増加したのは，式(6)を用いて亜鉛除去前の質量 $\left(\mathrm{W}_{1}\right)$ を測定する際 に酸化膜の質量も含まれたためである。また，計画腐食量が $116 \%$ ま で達した時点では，印加電流密度に関わらずほぼ同様な残存厚さと なった。この結果より, 本研究で水準とした印加電流密度の範囲で は, 電食速度の違いが実際の腐食量に及ぼす影響は小さいと考えら れる。一方, 酸化膜の厚さを推定するために, 本研究では式(6)を用 いて [健全部めっき鉄筋 $\left(\mathrm{W}_{0}\right)$ - 亜鉛皮膜の除去前の鉄筋 $\left.\left(\mathrm{W}_{1}\right)\right]$ の質量 差から予想值を求めた。W 1 は計画腐食量が $29 \%$ 時点でのめっき鉄 筋の平均值を適用した。その結果, 酸化膜の推定值は $47.64 \mu \mathrm{m}$ とな り, 本研究ではFig.11に示した[めっき鉄筋の残存厚さ]一酸化膜の 推定值]の結果から実際の腐食量 $(\%)$ を求めた。

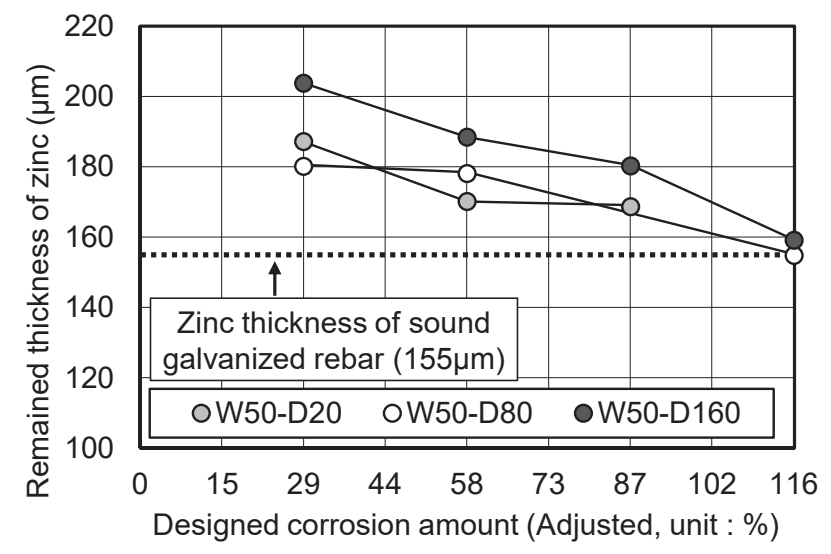

Fig.11 Remained coating thickness after corrosion test (series 1 ) 
Fig.12に計画腐食量と実際の腐食量の比較を示す。計画腐食量 $116 \%$ 時点での実際の腐食量は, 印加電流密度に関わらず約 $30 \%$ あ った。さらに, いずれの計画腐食量において実際の腐食量はほぼ一 定に増加する傾向にあった。この結果から, 本研究の範囲では, 印加 した積算電流量による計画腐食量に対しめっき鉄筋の実際の腐食量 は約 $1 / 4$ 程度であることがわかった。ただし，本研究での実際の腐食 量は，めっき鉄筋の防食効果がなくなる亜鉛腐食量までは進まなか った。従って, 低速の電食によってめっき鉄筋の防食効果が終了す る亜鉛腐食量を評価するためには, 積算電流量をより大きくして母 材の腐食が生じる時点を把握する必要があり，今後の課題とする。

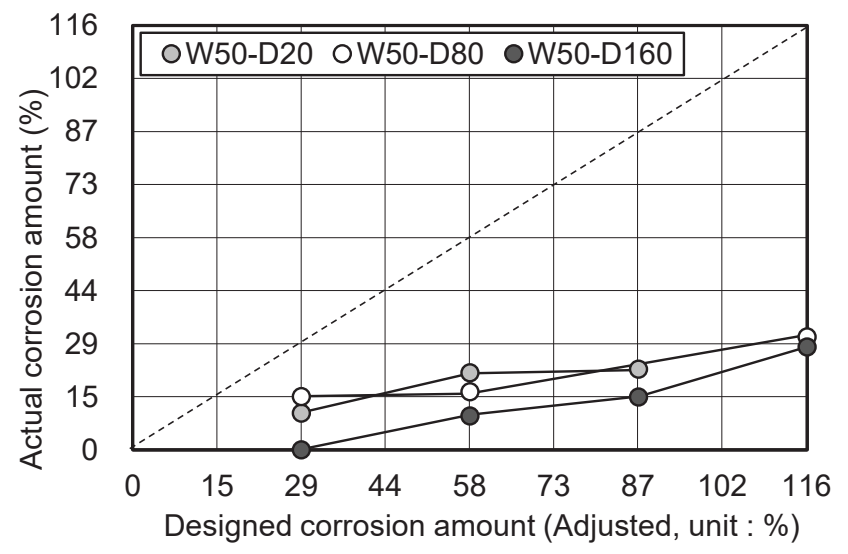

Fig.12 Actual and designed corrosion amount (series 1)

2) シリーズ2

\section{（1）電食後の分割鉄筋の表面変化}

Fig.13はA-1 A-4試験体の電食終了後の表面を示している。普通鉄 筋(鉄筋要素7)ではA-3 2 A-4 に少量の赤錆が生じた。めっき鉄筋では, シリーズ1と同様に，いずれの試験体も黒い酸化膜の形成が先行し, その後, 白い亜鉛腐食物 $\left(\mathrm{Zn}(\mathrm{OH})_{2}\right)$ が生じた。母材の腐食は生じなか った。中央部より外側部の腐食がより進行した局部腐食が現れ，異 種間接触によるマクロセル腐食が生じたと考えられる。一方, 局部 腐食の促進が普通鉄筋と近い中央部ではなかったことは, ステンレ 又鉄筋と接触した普通鉄筋の異種間腐食を評価した既往研究 33$)$,34) にも報告されている。本研究では, この現象の原因を把握するため に, A-4試験体を対象とし, 各鉄筋要素の腐食電流と腐食電位の挙動 を検討した。

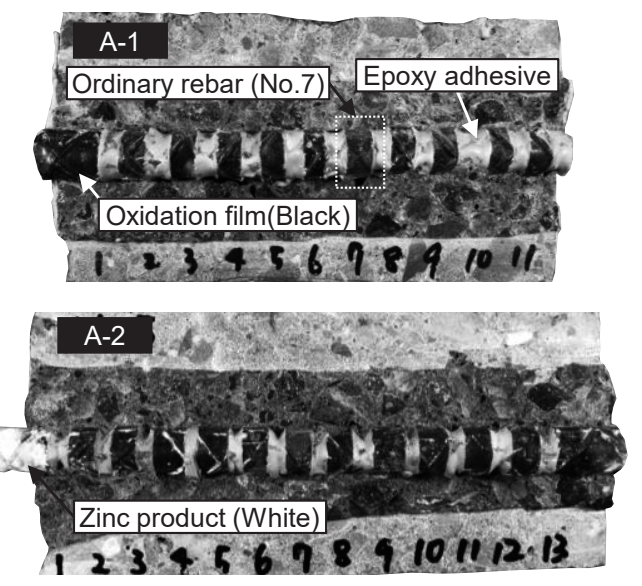

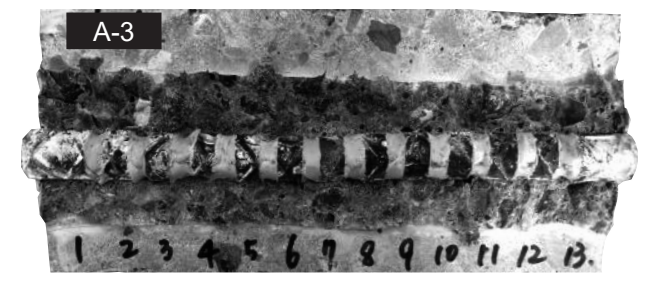

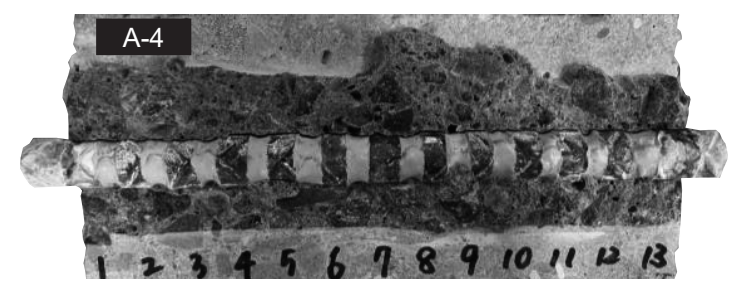

Fig.13 Surface change of the rebar after corrosion test (series 2)

\section{（2）亜鉛皮膜の実際の腐食量}

Fig.14は全試験体の実際の腐食量を示している。なお, シリーズ1 と同様，式(6)を用い予想の健全部質量 $\left(\mathrm{W}_{0}\right)$ と亜鉛除去後 $\left(\mathrm{W}_{2}\right)$ との質 量差 $\left(\mathrm{W}_{0}-\mathrm{W}_{2}\right)$ から算出した結果，各試験体が有する健全部の亜鉛皮 膜の平均厚さはそれぞれ異なる值となった。そのため, Fig.14の中に 表記の通りそれぞれの試験体に対し計画腐食量の補正を行った。ま た, 亜鉛皮膜の残存量 $\left(\mathrm{W}_{1}-\mathrm{W}_{2}\right)$ を求めた結果, シリーズ 1 と同様に, 酸化膜の影響によって予想の健全部より質量が増加する鉄筋要素が みられた(特に, A-3 試験体)。この鉄筋要素について本研究では腐食 量を“0”と仮定し，各鉄筋要素の実際の腐食量を求めた。

その結果，鉄筋要素によってばらつきはあるが，A-2を除き，A-1 と $\mathrm{A}-3 \sim \mathrm{A}-4$ 試験体において中央部より外側部のめっき鉄筋の腐食量 が比較的多くなり, Fig.13の結果とほぼ同様の傾向をしめした。特に, 鉄筋要素1と13において腐食の促進が確認された。一方, 補正した計 画腐食量と試験体の平均腐食量(鉄筋要素1 13の平均值)を比べてみ ると, A-1は積算電流量に応じてほぼ同じ程度の腐食が進行したが, A-2以降では積算電流量の増加にもかかわらず腐食の進展が遅くな る結果となった。計画腐食量に対しA-2 A-4の実際の腐食量の平均 は約 $2 / 5$ 程度であり, シリーズ 1 の結果と比較すると, 約 1.6 倍腐食が 促進されていることがわかった。一方ステンレス鉄筋と普通鉄筋の 異種間腐食を検討した既往研究34) 36)では, 異種間接触しても普通鉄 筋に影響がほとんど生じなかったと報告されている。従って, アノ 一ド金属の腐食が進まない条件であれば，めっき鉄筋と普通鉄筋の 併用においても異種間腐食の問題を軽減できると考えられる。

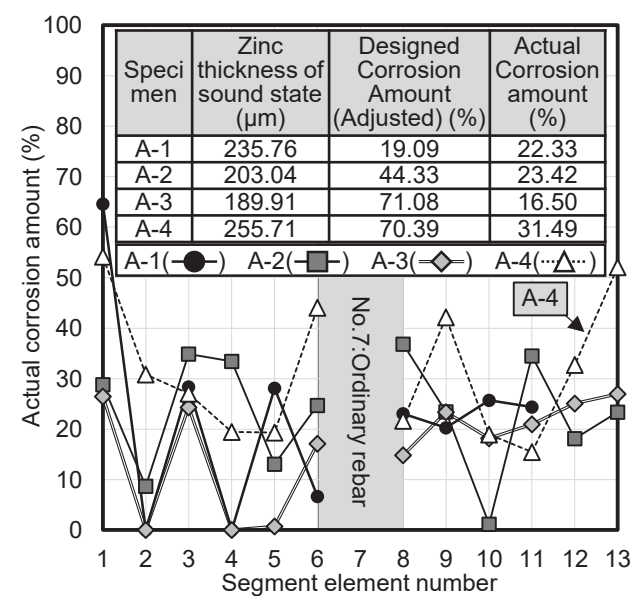

Fig.14 Actual corrosion amount of all specimens (series 2) 


\section{（3）腐食進行における電気化学的特性}

A-4試験体について, Fig.15は総腐食電流密度を, Fig.16はマクロ セル腐食電流密度を, Fig.17は腐食電位の分布を示している。本研究 では, 分割鉄筋の短絡によって異種間腐食が生じる時の腐食挙動を 比較するために, 最初の測定時点を短絡後7日とし, 計画腐食量は $0 \%$ とみなした。電食時間における計画腐食量は補正值を適用した。長 谷川ら ${ }^{28)}$ によると, 総腐食電流はミクロセル電流とマクロセル電流 を足し合わせた電流である。マクロセル電流において腐食反応にか かわる電流はアノード電流(正の值)のみであり, カソード電流(負の 值)は“0”として総腐食電流を求める。

Fig.15に示したA-4試験体の総腐食電流について, 鉄筋要素 $2 \sim 12$ はミクロセル電流とほぼ一致したが, 外側部の鉄筋要素 1 と 13 では正 のマクロセル電流が流れ(Fig.16), 総腐食電流が増加する結果となり, 異種間腐食の影響をうけることが確認できた。この結果はFig.13お よびFig.14ともおおむね一致した。一方鉄筋要素1 6において, 計画 腐食量が $17.6 \%$ 35.2\%では比較的高い総腐食電流の上昇がみられ, Fig.17に示した腐食電位においても不安定な分布が現れた。その後, 計画腐食量が $52.8 \%$ 70.4\%では電流変化が抑えられ, 鉄筋要素8 13 と同じ程度の腐食電流が確認された。補正した計画腐食量 $70.39 \%$ に 対しA-4の実際の腐食量が31.49\%であったことから，めっき鉄筋の 異種間腐食の影響は腐食初期に大きくなり，それ以降は一定な範囲 内で挙動すると考えられる。Fig.16に示したマクロセル電流の挙動 について，普通鉄筋はいずれの計画腐食量においてもカソード領域 にあった。さらに，めっき鉄筋は中央部のカソード電流が比較的高 くなり，外側部にあるほど減少することが確認された。この現象は 腐食電位の分布と相関があると考えられる。マクロセルの形成は隣 接した鉄筋間の電位差が原因であり，卑電位にあるほうがアノード 領域となる26) 28)。本実験において, 中央部と外側部のめっき鉄筋間 に電位差が生じたこと(Fig.17)，鉄筋要素1と13の腐食電位が最も低 くなってアノード領域が形成したこと(Fig.16)によって, 外側部に異 種間腐食の影響が顕著になったと考えられる。

一方, 計画腐食量が $0 \%$ 35.2\%では普通鉄筋の総腐食電流がめっき 鉄筋より比較的大きく現れた(Fig.15)。普通鉄筋と中央部めっき鉄筋 間の電流差は計画腐食量 $52.8 \%$ 以上で減少する結果となった。宮坂 37)によると, 異種間腐食とカソード防食は表裏一体の現象であり, 電位が異なる異種金属どうしが構成するマクロセルと報告している。 めっき鉄筋は亜鉛の犠牲陽極反応を用いるカソード防食であるので, 短絡によって普通鉄筋は亜鉛皮膜の損傷部として作用寸る可能性が ある。よって本研究の範囲では, 普通鉄筋に対し中央部めっき鉄筋 のカソード防食が計画腐食量 $52.8 \%$ 以上で生じていると推定される。

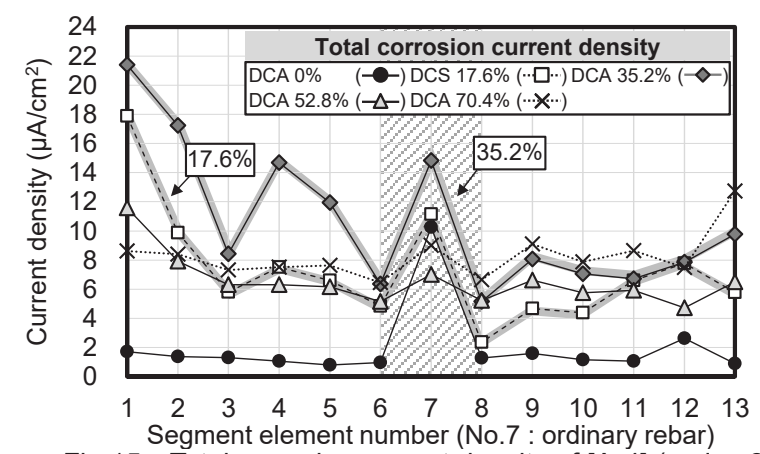

Fig.15 Total corrosion current density of $[A-4]$ (series 2)

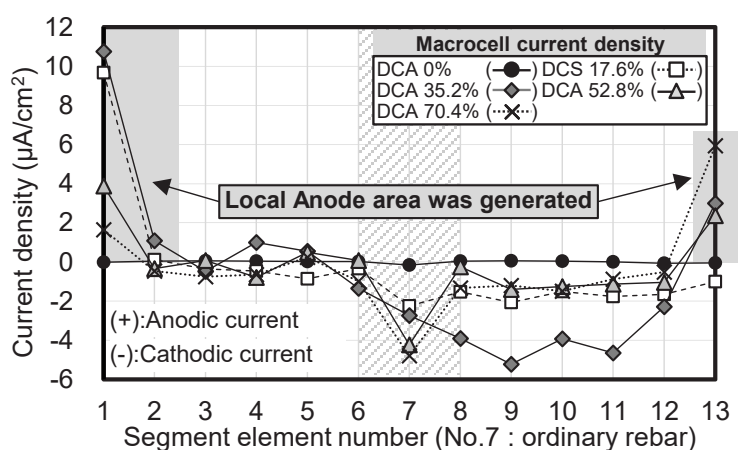

Fig.16 Macrocell corrosion current density of $[A-4]$ (series 2 )

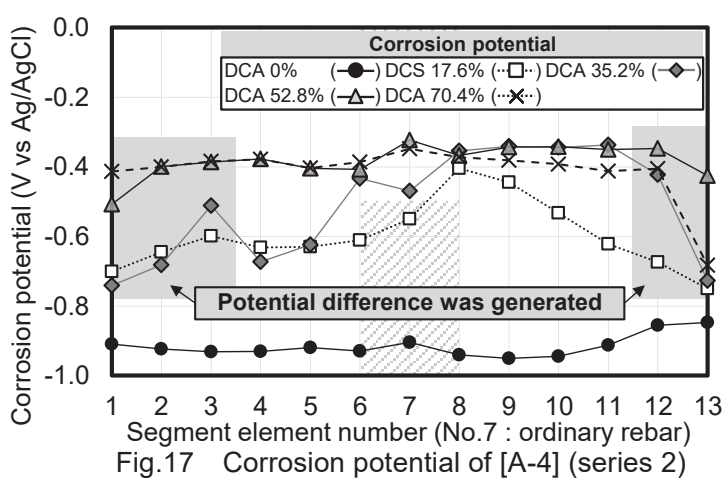

\section{4. 結論}

本研究では，比較的低速の電食をうけるめっき鉄筋が単一及び異 種間腐食の環境において正常に腐食するかを検討し, 腐食進行時の めつき鉄筋が有する犠牲防食効果(シリーズ 1 ) と異種間腐食の影響が 現れる範囲(シリーズ2)の評価を目的とした。その結果, 以下の結論 を得た。

1) シリーズ1において腐食進行によるめっき鉄筋の表面変化を観察 した結果, 黒い酸化膜が初期に形成し, その後, 亜鉛はいずれの表面 でも均一に腐食した。さらに，コンクリートのひび割れおよび母材 の腐食は生じなかった。この結果は実構造物のめっき鉄筋の腐食現 象とほぼ同様であり, 本研究で低速に設定した電食速度の範囲では めっき鉄筋の防食効果が正常に機能していることがわかった。

2)シリーズ1において分極抵抗の挙動は, 実際の腐食量との相関はみ られず, $\mathrm{Zn}(\mathrm{OH})_{2}$ と推定される亜鉛腐食物の形成挙動によって主な 影響を受けていることが確認された。腐食によって $\mathrm{Zn}(\mathrm{OH})_{2}$ が多く みられるほど分極抵抗は高くなったが，これはZn $(\mathrm{OH})_{2}$ が有する電 気的な絶縁特性が影響したと推定される。従って, 母材の腐食が生 じない限り, めっき鉄筋の腐食が進行するほど分極抵抗は徐々に増 加すると考えられる。

3)シリーズ1においてめつき鉄筋に形成した酸化膜は亜鉛皮膜の初 期に保護効果を有し，亜鉛の腐食開始以降には影響しないと推察さ れる。また, 計画腐食量と実際の腐食量の比較から, 単一腐食の環境 にあるめっき鉄筋は印加した積算電流量による計画腐食量に対し約 $1 / 4$ 程度の亜鉛皮膜が実際に腐食することがわかった。

4) シリーズ 2 におて, 電食終了後のめっき鉄筋はシリーズ1と同様 に酸化膜を形成し，母材の腐食は生じず，計画腐食量より低い実際 の腐食量が確認された。ただし, 亜鉛腐食物の生成が局部的に多く みられた分割鉄筋から, 異種間腐食が現れた範囲は普通鉄筋より遠 方あった外側部のめっき鉄筋であると確認された。なお，計画腐食 
量に対し約 $2 / 5$ 程度が腐食したことから, 異種間腐食の影響によって シリーズ1での結果に比べ約 1.6 倍腐食が促進されたことがわかった。 5) シリーズ2において異種間腐食が生じた原因は, 普通鉄筋の付近に あるめっき鉄筋と外側にあるめっき鉄筋間に腐食電位差が生じ，卑 電位を示した外側部のめっき鉄筋に局部アノード領域が形成され, 腐食に関るマクロセル電流が流れたためであると確認された。 $\mathrm{A}-4$ 試 験体の結果から,この現象は計画腐食量 $17.6 \%$ 35.2\%の腐食初期に 顕著であり，総腐食電流の上昇となった。

\section{参考文献}

1) Niwa, A. et al.: The Bonding Performance of Hot-dip Galvanized Steel in the Concrete with regard to its Corrosion Behavior, Proceedings of the JCI, Vol. 40, No. 1, pp. 969-974, 2018.7 (in Japanese) 丹羽章暢ほか 2 名：溶融亜鉛めっき鉄筋の腐食がコンクリートの付着性能に 与える影響, コンクリート工学年次論文集, Vol. 40, No. 1, pp. 969-974, 2018. 7

2) Choe, H.B., Nishio, Y. and Kanematsu, M.: An Experimental Study on Galvanic Corrosion of Galvanized Steel Reinforcement in Contact with Ordinary Steel Reinforcement, The 18th JSMS Symposium on Concrete Structure Scenarios, Vol. 18, pp. 19-24, 2018. 10 (in Japanese) チェホンボク, 西尾悠平, 兼松学: 溶融亜鉛めっき鉄筋の普通鋼鉄筋との異 種間接触における腐食挙動に関する実験的研究, コンクリート構造物の補 修，補強，アップグレード論文報告集，Vol. 18, pp. 19-24, 2018. 10

3) Fukumoto, S., Ueda, T. and Tsukagoshi, M.: Corrosion and Bond Properties of Galvanized Reinforcing Steel in Concrete, Proceedings of the JCI, Vol. 40, No. 1, pp. 939-944, 2018. 7 (in Japanese)

福本信吾ほか 2 名：コンクリート中における亜鉛めっき鉄筋と付着特性に関 する検討，コンクリート工学年次論文集, Vol. 40, No. 1, pp. 939-944, 2018. 7

4) Takeshita, R. et al.: Corrosion of Galvanized Steel Bar in Ocean exposure Concrete, Proceedings of the JCI, Vol. 40, No. 1, pp. 963-968, 2018.7 (in Japanese)

竹下麗華ほか 3 名：海洋暴露したコンクリート中亜鉛めっき鉄筋の腐食につ いて, コンクリート工学年次論文集, Vol. 40, No. 1, pp. 963-968, 2018. 7

5) Sakihara, K., Yamada, Y. and Sunabe, K.: Study on Corrosion Prediction of Hot-dip Galvanized Rebar in Concrete, The 18th JSMS Symposium on Concrete Structure Scenarios, Vol. 18, pp. 167-172, 2018. 10 (in Japanese) 崎原康平, 山田義智, 砂邊景福: コンクリート中に埋設された溶融亜鉛めっ き鉄筋の腐食予測に関する研究, コンクリート構造物の補修, 補強, アップ グレード論文報告集, Vol. 18, pp. 167-172, 2018. 10

6) Takeshita, R. et al.: Corrosion Performance Protection of Zinc Galvanized Steel Bar under High Alkali Environment, Proceedings of the JCI, Vol. 39, No. 1, pp. 967-972, 2017. 7 (in Japanese)

竹下麗華ほか3名：高アルカリ性環境下における亜鉛めっき鉄筋の防食性能, コンクリート工学年次論文集, Vol. 39, No. 1, pp. 967-972, 2017. 7

7) Stark, D. and Perenchio, W.F.: The performance of galvanized reinforcement in concrete bridge decks, ILZRO Project ZE-206, International Lead Zinc Research Organization, NC, USA, 1975

8) Stark, D.: Galvanized reinforcement in concrete containing chlorides, ILZRO Project ZE-247. International Lead Zinc Research Organization, NC, USA, 1978

9) Stark, D.: Evaluation of the performance of galvanized reinforcement in concrete bridge decks. ILZRO Project ZE-320. International Lead Zinc Research Organization, NC, USA, 1982

10) Stejskal, B.G.: Evaluation of the performance of galvanized steel reinforcement in concrete bridge decks. CTL Project 050324. Construction Technology Laboratories Inc, Skokie, IL, 1992

11) Olson, C.A. and Nagi, M.A.: Evaluation of the performance of galvanized steel in concrete bridge decks, ILZRO Project ZC-10. Construction Technology Laboratories, Inc, Skoki, IL, 39p, 2002

12) Japan Society of Civil Engineers: Guideline on Design and Application
Methods of Galvanized Steel Reinforcement for Concrete Structures, Japan Society of Civil Engineers, 2019

土木学会：亜鉛めっき鉄筋を用いるコンクリート構造物の設計・施工指針 (案), 土木学会, 2019

13) Yeomans, R. S.: Galvanized Steel Reinforcement in Concrete, Elseiver, 2004. 11

14) Takaya, S. et al.: Formation Process and Electrochemical Property of Steel Corrosion Products in Concrete, Journal of JSCE, Ser. E2 (Materials and Concrete Structures), Vol. 71, No. 3, pp. 235-247, 2015. 7 (in Japanese)

高谷哲ほか 4 名：コンクリート中における鉄筋の腐食生成物の生成プロセス および電気化学的特性, 土木学会論文集 E2 (材料・コンクリート構造), Vol. 71, No. 3, pp. 235-247, 2015. 7

15) Yamamoto, T.: Study on Structural Performance of Concrete Structures with Corroded Reinforcing Steel-Approaches by Dr. Toyoaki Miyagawa and Dr. Koji Takewaka-, Concrete Journal, Vol. 51, No. 9, pp. 769-776, 2014. 9 (in Japanese)

山本貴士：鋼材腐食を生じたコンクリート構造物の構造性能研究一宮川豊章 博士, 武若耕司博士らのアプローチー, コンクリート工学, Vol. 51, No. 9, pp. 769-776, 2014. 9

16) Kuroda, I. et al. : Estimation Method of Flexural Capacity of RC-Beams with Corroded Re-bars based on Crack Width and Wave Velocity, Journal of JSCE, Ser. E2 (Materials and Concrete Structures), Vol. 70, No. 3, pp. 272-288, 2014 (in Japanese)

黒田一郎, 村上将也, 山本佳士，古屋信明：ひび割れ幅と超音波伝搬速度に よる鉄筋腐食 $\mathrm{RC}$ 梁の曲げ耐力推定手法, 土木学会論文集 $\mathrm{E} 2$ (材料・コンクリ 一ト構造), Vol. 70, No. 3, pp. 272-288, 2014

17) Takaya, S., et al.: Influence of Steel Corrosion Products in Concrete on Crack Opening Weight Loss of Corrosion, Journal of JSCE, Ser. E2 (Materials and Concrete Structures), Vol. 69, No. 2, pp. 154-165, 2013. 4 (in Japanese)

高谷哲, 中村士郎, 山本貴士, 宮川豊章: コンクリート中の鉄筋の腐食生成 物の違いがひび割れ発生腐食量に与える影響, 土木学会論文集E2(材料・コ ンクリート構造), Vol. 69, No. 2, pp. 154-165, 2013. 4

18) Care, S. et al.: Mechanical Properties of the Rust Layer Induced by Impressed Current Method in Reinforced Mortar, Cement and Concrete Research, Vol. 38, Issues 8-9, pp. 1079-1091, 2008. 3

19) Yuan, Y. et al.: Comparison of Two Accelerated Corrosion Techniques for Concrete Structures, ACI Structural Journal, Vol. 104, No. 3, pp. 344-347, 2007. 6

20) Vu, K., et al:: Corrosion-Induced Cracking: Experimental Data and Predictive Models, ACI Structural Journal, Vol. 102, No. 5, pp. 719-726, 2005. 9

21) El Maaddawy, T.A. and Soudki, K.A.: Effectiveness of Impressed Current Technique to Simulate Corrosion of Steel Reinforcement in Concrete, Journal of Materials in Civil Engineering, Vol. 15, No. 1, pp. 41-47, 2003. 2

22) Onishi, H., et al.: Experimental Study on the Durability of the Reinforced Concrete Members Covered with Surface Lining, Journal of Applied Mechanics, Vol. 5, pp. 935-944, 2002 (in Japanese)

大西弘志ほか 3 名：表面被覆された鉄筋コンクリート部材の耐久性に関する 実験的研究, 土木学会応用力学論文集, Vol. 5, pp. 935-944, 2002

23) Bresler, B. and Cornet, I.: Corrosion Protection of Steel in Concrete and Tentative Recommendations for Use of Galvanized Steel Reinforcement in Concrete, ILZRO Report TS-69-04, International Lead Zinc Research Organization, NC, USA, 1969

24) Cornet, I. and Bresler, B.: Corrosion of Steel and Galvanized Steel in Concrete, Materials Protection, Vol. 5, No. 4, pp. 69-72, 1966

25) Galvanizer's Association of Australia : After-Fabrication Hot Dip Galvanizing, 1999

26) Miyazato, S. et al.: Bunkatsu tekkin o mochiita makuro seru denryū sokutei hōhō no jikken-teki riron-teki kentō (Experimental and 
Theoretical investigation on measurement method of macrocell current by means of segmented rebar), Proceedings of the JCI, Vol. 23, No. 2, pp. 547-552, 2001. 6 (in Japanese)

宮里心一, 大即信明，小長井彰祐：分割鉄筋を用いたマクロセル電流測定方 法の実験的・理論的検討, コンクリート工学年次論文集, Vol. 23, No. 2, pp. 547-552, 2001. 6

27) Miyazato, S. and Otsuki, N.: The Estimation of Macrocell Corrosion Rate of Rebar in Existing Concrete using Non-destructive Tests, Concrete Research and Technology, Vol. 12, No. 2, pp. 93-103, 2001 (in Japanese) 宮里心一, 大即信明：既存鉄筋コンクリート部材中のマクロセル腐食速度の 推定, コンクリート工学論文集, Vol. 12, No. 2, pp. 93-103, 2001

28) Hasegawa, Y., et al.: Proposal of Corrosion Rate Analytical Model of Reinforced Concrete with Crack, Concrete Research and Technology, Vol. 17, No. 1, pp. 31-39, 2006 (in Japanese)

長谷川裕介ほか 3 名：ひび割れを有する鉄筋コンクリートの腐食速度解析モ デルの提案, コンクリート工学論文集, Vol. 17, No. 1, pp. 31-39, 2006

29) JIS H 0401 : 2013 : test methods for hot dip galvanized coatings (in Japanese) JIS H $0401 ： 2013$ ：溶融亜鉛めつき試験方法

30) Powers, R.W. and Breiter, M.W.: The Anodic Dissolution and Passivation of Zinc in Concentrated Potassium Hydroxide Solutions, Journal of the Electrochemical Society, Vol. 116, pp. 719-729, 1969

31) Murakami, K., et al.: Adhesion Characteristics between Hot Dip Galvanized Steel and Concrete, Lead \& zinc, Vol. 229, pp. 38-43, 2003 (in Japanese)

村上和美, 前川明弘, 湯浅幸久 : 溶融亜鉛めっきとコンクリートの付着特 性について, 鉛と巠鉛, Vol. 229, pp. 38-43, 2003

32) Hasimoto, S.: Relationship between Fine Structure of Coatings and their Corrosion Resistance for Zinc System Coated Steel Sheets, Hyomen Kagaku, Vol. 22, No. 2, pp. 128-135, 2001 (in Japanese)

橋本哲：亜鈶系めっき皮膜の構造と耐食性，表面科学, Vol. 22, No. 2, pp. 128-135, 2001

33) Ando, S., et al.: Galvanic Coupling between Carbon Steel and Stainless Steel in Concrete Containing High Amount of Chloride Ion, Proceedings of the JCI, Vol. 36, No. 1, pp. 1246-1251, 2014. 7 (in Japanese) 安藤智史, 河野広隆, 服部篤史, 石川敏之: 塩化物イオン高含有コンクリー ト中のSUS鉄筋との接触が普通鉄筋の腐食に与える影響, コンクリート工 学年次論文集, Vol. 36, No. 1, pp. 1246-1251, 2014. 7

34) Kakihara, T., et al.: Effect of Galvanic Corrosion on Rebar Corrosion of Stainless Reinforced Concrete Structure: Part1 Experimental Investigation, Summaries of Technical Papers of Annual Meeting, Architectural Institute of Japan, A-1, pp. 565-566, 2011. 7 (in Japanese) 柿原巧弥, 千歩修, 長谷川拓哉, 山下恵介：ステンレス鉄筋コンクリート造 建築物の鉄筋腐食に及ぼす異種金属接触腐食の影響 : その 1 実験的検討, 日本建築学会大会学術講演梗概集, A-1, pp. 565-566, 2011. 7

35) Maruya, J. and Niwa, J.: Recommendations for Design and Construction of Concrete Structures Using Stainless Steel Bars Draft, Concrete Journal, Vol. 46, No. 12, pp. 3-10, 2008 (in Japanese) 丸屋剛, 二羽淳一郎：ステンレス鉄筋を用いるコンクリート構造物の設計施 工指針(案)の概要, コンクリート工学, Vol. 46, No. 12, pp. 3-10, 2008

36) Shinoda, Y., Yamaji, T., Kawano, H. and Nagataki, S.: An Experimental Study on the Corrosion Resistance Performance of Stainless Steel Bars in Concrete, Proceedings of the JCI, Vol. 29, No. 1, pp. 1335-1340, 2007. 7 (in Japanese) 篠田佳男ほか 3 名：コンクリート中のステンレス鉄筋の耐食性能に関する実験 的研究, コンクリート工学年次論文集, Vol. 29, No.1, pp.1335-1340, 2007. 7

37) Miyasaka, S. et al.: Kyōkaiyōso kaiseki ni yoru kaisui ponpu no bōshoku sekkei (Anti-corrosion design of seawater pump by boundary element analysis), Turbomachinery, Vol. 23, No. 10, pp. 590-596, 1995 (in Japanese)

宮坂松甫ほか3名：境界要素解析による海水ポンプの防食設計, ターボ機械, Vol. 23, No. 10, pp. 590-596, 1995 


\title{
A STUDY ON ANTI CORROSION BEHAVIOR OF GALVANIZED STEEL REBAR IN CONCRETE UNDER GENERAL AND GALVANIC COUPLED ENVIRONMENT
}

\author{
Hongbok $\mathrm{CHOE}^{* 1}$, Yuhei NISHIO ${ }^{* 2}$ and Manabu KANEMATSU ${ }^{* 3}$ \\ ${ }^{* 1}$ Grad. Student, Dept. of Architecture, Grad. School of Sci. and Tech., Tokyo Univ. of Sci., M.Eng. \\ *2 Assist. Prof., Dept. of Architecture, Faculty of Sci. and Tech., Tokyo Univ. of Sci., Dr.Eng. \\ ${ }^{* 3}$ Prof., Dept. of Architecture, Faculty of Sci. and Tech., Tokyo Univ. of Sci., Dr.Eng.
}

Recently, studies on anti-corrosion performance of galvanized steel rebar (hereafter, HDZ bar) have been carried out. HDZ bar is known to perform sacrificial anodic reaction by zinc. While it is subjected to corrosion, zinc coating continuously corrodes itself replacing for steel substrate. Meanwhile, in order to expand the usability of HDZ bar in RC structure, two things are regarded which are durability examination of corroded HDZ bar and a partial application of HDZ bar where active corrosion is predicted.

Concerning the durability examination, accelerated corrosion test which induces anodic current to the rebar has been used. However, in using this test on HDZ bar, the influence of applied current density has not yet been clarified. Although there was an attempt which applied $0.625 \mathrm{~mA} / \mathrm{cm}^{2}$ of current density, the result showed that HDZ bar performed its anti-corrosion effect to the maximum when it is $43 \%$ corroded. About using HDZ bar and ordinary rebar together in concrete, there has been a concern on galvanic corrosion of HDZ bar. Electrical connection between HDZ bar and ordinary rebar causes accelerated local corrosion of HDZ bar at contacted area. Nonetheless, it has not been fully clarified on which area is locally corroded.

In this study, in order to investigate the suitability of accelerated corrosion test, relatively lower range of applied current density was tested on HDZ bar as series1. A designed corrosion amount (hereafter, DCA) was considered which intends full dissolution of zinc coating. In series2, in order to investigate the galvanic corrosion, segmented rebar was experimentally attempted to evaluate macrocell corrosion behavior. Galvanic corrosion was regarded as macrocell corrosion caused by formation of anode and cathode region.

As a result, in series1, HDZ bar showed continuous anti-corrosion effect and no corrosion of substrate and concrete crack were found within 100\% of DCA. In electrochemical evaluation, HDZ bar showed relatively high polarization resistance $\left(R_{p}\right)$ as the applied current density is lower. Furthermore, $R_{p}$ was increased with corrosion progress. It is assumed that a formation of $\mathrm{Zn}(\mathrm{OH})_{2}$ on the surface was decisive because it is known as insulating material. In actual corrosion amount, approximately 1/4 of zinc coating was corroded against DCA.

In the result of series2, as similar to series 1, continuous anti-corrosion effect of HDZ bar, formation of oxidation film and no corrosion of substrate was identified. Actual corrosion amount of HDZ bar was also smaller than DCA. However, $2 / 5$ of zinc coating was corroded which is assumed by influence of galvanic couple. A potential difference was generated among segments of HDG bar. By this influence, anodic macrocell current was formed where it was the farthest from ordinary rebar. In conclusion, HDZ bar performed adequate anti-corrosion behavior in both corrosion environment in the scope of this study. 